\title{
Ectopic aldosterone-producing tumor
}

INSERM

\section{Source}

INSERM. (1999). Orphanet: an online rare disease and orphan drug data base. Ectopic aldosterone-producing tumor. ORPHA:231632

Ectopic aldosterone-producing tumor is an extremely rare aldosterone-producing neoplasm composed of aberrant adrenocortical tissue located outside the adrenal glands (e.g. in retroperitoneum, perirenal or periaortic fatty tissue, thorax, spinal canal, testes, ovaries) typically characterized by symptoms related to increased aldosterone levels (such as sustained, treatment-resistant hypertension and hypokalemia) or symptoms caused by local tumor enlargement. 